\title{
Transcriptional profiling of chickpea genes differentially regulated in response to high-salinity, cold and drought Nitin L Mantri ${ }^{1}$, Rebecca Ford ${ }^{* 2}$, Tristan E Coram ${ }^{3}$ and Edwin CK Pang ${ }^{1}$
}

Address: ${ }^{1}$ RMIT University, School of Applied Sciences, Biotechnology and Environmental Biology, Building 223, Level 1, Plenty Road, Bundoora, Victoria. 3083. Australia, ${ }^{2}$ BioMarka, Faculty of Land and Food Resources, The University of Melbourne, Victoria. 3010. Australia and ${ }^{3}$ United States Department of Agriculture, Agricultural Research Service, Wheat Genetics, Quality, Physiology and Disease Research Unit and Department of Plant Pathology, Washington State University, Pullman, WA, 99164-6430. USA

Email: Nitin L Mantri - nitin_mantri@rediffmail.com; Rebecca Ford* - rebeccaf@unimelb.edu.au; Tristan E Coram -tcoram@mail.wsu.edu; Edwin CK Pang - eddie.pang@rmit.edu.au

* Corresponding author

Published: 2 September 2007

BMC Genomics 2007, 8:303 doi:10.1/86/147|-2/64-8-303
Received: 26 April 2007

Accepted: 2 September 2007

This article is available from: http://www.biomedcentral.com//47I-2/64/8/303

(C) 2007 Mantri et al; licensee BioMed Central Ltd.

This is an Open Access article distributed under the terms of the Creative Commons Attribution License (http://creativecommons.org/licenses/by/2.0), which permits unrestricted use, distribution, and reproduction in any medium, provided the original work is properly cited.

\begin{abstract}
Background: Cultivated chickpea (Cicer arietinum) has a narrow genetic base making it difficult for breeders to produce new elite cultivars with durable resistance to major biotic and abiotic stresses. As an alternative to genome mapping, microarrays have recently been applied in crop species to identify and assess the function of putative genes thought to be involved in plant abiotic stress and defence responses. In the present study, a cDNA microarray approach was taken in order to determine if the transcription of genes, from a set of previously identified putative stressresponsive genes from chickpea and its close relative Lathyrus sativus, were altered in chickpea by the three abiotic stresses; drought, cold and high-salinity. For this, chickpea genotypes known to be tolerant and susceptible to each abiotic stress were challenged and gene expression in the leaf, root and/or flower tissues was studied. The transcripts that were differentially expressed among stressed and unstressed plants in response to the particular stress were analysed in the context of tolerant/susceptible genotypes.
\end{abstract}

Results: The transcriptional change of more than two fold was observed for 109, 210 and 386 genes after drought, cold and high-salinity treatments, respectively. Among these, two, 15 and 30 genes were consensually differentially expressed (DE) between tolerant and susceptible genotypes studied for drought, cold and high-salinity, respectively. The genes that were DE in tolerant and susceptible genotypes under abiotic stresses code for various functional and regulatory proteins. Significant differences in stress responses were observed within and between tolerant and susceptible genotypes highlighting the multiple gene control and complexity of abiotic stress response mechanism in chickpea.

Conclusion: The annotation of these genes suggests that they may have a role in abiotic stress response and are potential candidates for tolerance/susceptibility.

\section{Background}

Chickpea (Cicer arietinum L.) is an annual, self-pollinat- ing, diploid $(2 \mathrm{n}=2 \mathrm{x}=16)$ pulse crop that ranks third in world legume production [1]. Australia is currently the 
largest exporter of chickpea and yield for 2006-2007 has been forecasted at 239,000 tonnes, most of which will be exported (225,000 tonnes) [2]. Under optimum growing conditions, the yield potential of chickpea is $6 \mathrm{t} / \mathrm{ha}$ [3], which is much higher than the current global yield average of $\sim 0.8 \mathrm{t} / \mathrm{ha}$ [1]. The chief constraints in chickpea production are biotic stresses like Ascochyta blight, Fusarium wilt, pod borer, and abiotic stresses such as drought, heat, cold and high-salinity [4]. In fact, the estimated collective yield losses due to abiotic stresses (6.4 million t) have been significantly higher than for biotic stresses (4.8 million t) [4]. Drought, a severe abiotic stress of chickpea, causes a $40-50 \%$ reduction in yield globally [1]. The change from spring to winter sowing of chickpea for efficient utilization of rain water in Mediterranean environments has enhanced yields, but demands tolerance to low temperature for further yield improvements [5]. Most legumes are known to be salt sensitive [6], and the increasing worldwide use of irrigation has led to the prediction that, by $2050,50 \%$ of all arable land will be salinized [7]. Therefore, it is becoming increasingly important to produce cultivars tolerant to high-salinity in addition to other abiotic and biotic stresses for sustainable chickpea production.

The cultivated chickpea has a high morphological but narrow genetic variation [8], which makes it difficult for breeders to produce elite cultivars with durable resistance to the many major biotic and abiotic stresses. Molecular markers associated with quantitative trait loci (QTL) for resistance to biotic stresses and some morphological traits have been located on both interspecific [9-18] and intraspecific linkage maps [19-22]. However compared to some biotic stresses, abiotic stresses are inherited in a more quantitative manner and may be subjective to assess under field conditions due to confounding environmental factors, which makes it difficult to screen for and quantitate tolerance. Quantitating the effects of abiotic stresses involves measurement of various factors like survival rate, yield, dry matter production, days to maturity, flower/pod survival, root mass and transpiration ratio. Their tolerances are likely to be quantitatively controlled and this feature of abiotic stresses represents a major obstacle to developing molecular markers.

Marker-assisted breeding is increasingly targeted towards tracking the candidate genes responsible for stress tolerance through gene identification and functional studies [23]. Candidate genes, identified and characterized through whole genome sequencing projects or expressed sequence tag (EST) libraries, are assessed for their comparative transcriptional activity against biological reactions to specific plant stresses via microarray technologies. Analysis of the expression and function/s of stress inducible genes facilitates understanding of the molecular mecha- nisms underlying the stress tolerance responses. This approach has potential to assist molecular plant breeders in improving stress tolerance by gene selection and/or genetic manipulation. Gene expression studies using ESTbased cDNA microarrays were pioneered by analysing 48 Arabidopsis genes for differential expression in roots and shoots [24]. The technology has subsequently been used extensively to generate expression profiles of genes linked to drought, heat, cold and salt stresses [25-29]. In order to obtain a complete picture of a plant's response to stress, it would be ideal to study the expression profiles of all the genes in its genome. Currently, this is only possible for model crops like Arabidopsis thaliana (thale cress), Oryza sativa (rice), Medicago truncatula (barrel medic), Populus trichocarpa (black cottonwood) whose genomes have been sequenced. In near future it shall be possible for Brachypodium distachyon, Lotus japonicus (lotus), Manihot esculenta (cassava), Solanum lycopersicum (tomato), Solanum tuberosum (potato), Sorghum bicolor and Zea mays (corn) whose genome sequencing shall be soon completed [30]. Until this is available for other crops, researchers have to rely on information generated by studying these model crops and explore the EST/cDNA sequences from same/related species generated by various studies. For pulses, a set of chickpea unigenes [31], grasspea ESTs [32] and lentil RGA sequences (Barkat Mustafa, pers. comm.) enriched for stress-responsive transcripts have recently become available, allowing the construction of a boutique microarray.

The aim of the study was to utilize the pulse microarray to identify transcripts linked to biological reactions (and hence potential survival) against the major abiotic stresses of drought, cold and high-salinity in chickpea. Expression profiling of chickpea genotypes tolerant and susceptible to these abiotic stresses was performed and the transcripts differentially expressed between stressed and unstressed plants were detected. Transcripts consensually differentially expressed between stress tolerant and susceptible genotypes were identified as belonging to potentially common biological pathways.

\section{Results and discussion Experimental design and analysis}

The advent of microarrays has enabled the screening of thousands of genes in parallel to assist in candidate gene identification. Ideally, one would like to scan the entire genome of a particular plant to obtain a more complete picture of transcriptional changes in response to various stresses. However, whole genome sequences are not available for most crops, leading to a dependence on collections of ESTs assembled from random cDNA libraries. For pulses, a set of chickpea unigenes, grasspea ESTs and lentil RGA sequences were recently employed for the construction of a boutique array enriched with stress-related genes [33]. Although the two main source of ESTs for this array 
were derived from plant tissue challenged with biotic stress (pathogen), it was clear from annotation of the ESTs that many may also be associated with abiotic stress [as seen in $[34,27,29]$. In fact, a considerable amount of interaction was revealed between wounding, pathogen, abiotic stress and hormonal responses in Arabidopsis by transcriptional profiling [35]. Many genes identified by salt-stress expression studies were reported to be common with pathogen infection [36], whilst a review on abiotic and biotic stress responses in plants [37] concluded that a significant amount of crosstalk exists in the stress signalling networks. Therefore, in the absence of a purely abiotic stress related cDNA library for chickpea, the boutique pulse array was considered an excellent tool for studying the chickpea transcriptome in response to abiotic stresses.

Expression profiling of chickpea in response to the abiotic stresses of drought, cold and high-salinity has not been previously documented. The experimental design of this study was carefully chosen to target adaptive genes, in tolerant and susceptible genotypes, by attempting to simulate natural conditions. This was achieved by cultivating plants in a glasshouse instead of growth chamber, and by applying uniform and prolonged stress before harvesting tissue samples. Moreover, it was known that chickpea is most sensitive to drought and cold stresses at flowering [38-41], thus this study examined both the leaf and flower response for drought and cold stresses. However, considering that plants usually face salinity stress from the vegetative stage (if grown on saline soils), the high-salinity stress was applied in an early growth stage. Further, the time-points chosen for tissue collection after high-salinity stress were based on the results of a pilot experiment that showed that two-week old chickpea plants could not prevent salt from reaching leaves after $48 \mathrm{~h}$ of stress with 150 $\mathrm{mM} \mathrm{NaCl}$ (data not shown).

The microarray experiments were conducted in a reference design, where tissue samples from unstressed plants acted as references against stressed plants. The tolerant and susceptible genotypes were challenged with abiotic stress in a standardized system that minimized experimental variability and ensured accurate measurements of changes in transcript abundance (Figure 1). All expression data was deposited in Minimum Information About a Microarray Experiment (MIAME) compliant format at Gene Expression Omnibus, National Center for Biotechnology Information [GEO: SuperSeries GSE7504]. The microarray observations were validated by quantitative reverse transcription-polymerase chain reaction (qRT-PCR) for sev-

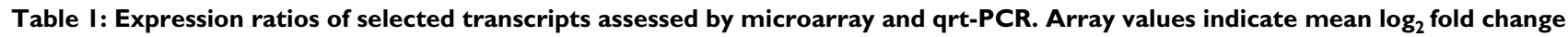
(FC) ratio relative to untreated controls and $q R T-P C R$ values indicate $\log _{2}$ ratios of $2^{\wedge}\left(\Delta C_{t} \operatorname{control} / \Delta C_{t}\right.$ treatment). $A$ set of $D E$ genes that were expressed in both the tolerant/susceptible genotypes were chosen for qRT-PCR confirmation of expression.

\begin{tabular}{|c|c|c|c|c|c|c|}
\hline \multirow{2}{*}{$\begin{array}{l}\text { Treatment/ } \\
\text { Genotype/Tissue- } \\
\text { type }\end{array}$} & \multirow{2}{*}{$\begin{array}{l}\text { GenBank } \\
\text { Accession }\end{array}$} & \multirow[t]{2}{*}{ Putative Function } & \multicolumn{2}{|c|}{ Group I* } & \multicolumn{2}{|c|}{ Group II* } \\
\hline & & & Array & qPCR & Array & qPCR \\
\hline Cold tolerant leaves & DY475384 & $\begin{array}{l}\text { Similar to serine/ } \\
\text { threonine protein } \\
\text { kinase }\end{array}$ & -2.43 & -2.95 & -3.27 & -3.79 \\
\hline Cold susceptible flowers & DY475397 & $\begin{array}{l}\text { Superoxide dismutase } \\
\text { copper chaperone } \\
\text { precursor involved in } \\
\text { oxidative stress }\end{array}$ & -4.16 & -4.53 & -1.47 & -2.65 \\
\hline $\begin{array}{l}\text { Drought susceptible } \\
\text { flowers }\end{array}$ & DY475477 & $\begin{array}{l}\text { Asparagine synthetase } \\
\text { (glutamine } \\
\text { hydrolysing) (EC } \\
6.3 .5 .4) \text { - induced by } \\
\text { the dark. }\end{array}$ & -2.66 & -2.37 & 1.08 & 3.71 \\
\hline $\begin{array}{l}\text { Salt tolerant shoot } 24 \\
\text { hpt }\end{array}$ & DY47550I & $\begin{array}{l}\text { Chloroplast DNA for } \\
\text { P700 chlorophyll a- } \\
\text { apoproteins }\end{array}$ & -1.06 & -2.43 & -2.13 & -3.56 \\
\hline $\begin{array}{l}\text { Salt tolerant root } 24 \\
\text { hpt }\end{array}$ & DY475I24 & Aquaporin & -1.73 & -2.84 & -1.00 & -2.17 \\
\hline $\begin{array}{l}\text { Salt susceptible root } 24 \\
\text { hpt }\end{array}$ & DY475225 & $\begin{array}{l}\text { Proline oxidase } \\
\text { enzyme involved in } \\
\text { the conversion of } \\
\text { proline to glutamate - } \\
\text { induced by osmotic } \\
\text { stress }\end{array}$ & -1.19 & -1.83 & -2.64 & -3.12 \\
\hline $\begin{array}{l}\text { Salt tolerant root } 48 \\
\text { hpt }\end{array}$ & DY475403 & $\begin{array}{l}\text { Carbonic anhydrase } \\
\text { like protein }(E C \\
4.2 .1 .1)- \text { reversible } \\
\text { hydration of carbon } \\
\text { dioxide }\end{array}$ & -1.47 & -2.61 & -2.36 & -2.93 \\
\hline $\begin{array}{l}\text { Salt susceptible root } 48 \\
\text { hpt }\end{array}$ & DY475408 & Xylosidase & 2.48 & 2.73 & 1.09 & 1.67 \\
\hline
\end{tabular}

\footnotetext{
* The tolerant/susceptible genotypes used in Group I and Group II are mentioned in Table 4.
} 
eral representative transcripts (Table 1). Eight genes that were commonly DE in both the tolerant/susceptible genotypes from all the stresses, time-points and tissue-types were selected for qRT-PCR validation. The comparison of expression values between the two methods revealed similar expression kinetics for all the genes tested indicating reliability of the microarray data. The expression values obtained by qRT-PCR were generally more exaggerated than the corresponding microarray values, which have also been reported in previous studies $[33,42,43]$.

In general, the results showed that the level of several transcripts was altered by more than one of the stresses assessed (Figure 2), which may indicate gene interaction/ shared pathways among the biological responses involved in these stress reactions. The number of differentially expressed (DE) transcripts affected in response to highsalinity was much higher than those affected in response to cold and drought stress in all genotypes. In Arabidopsis,

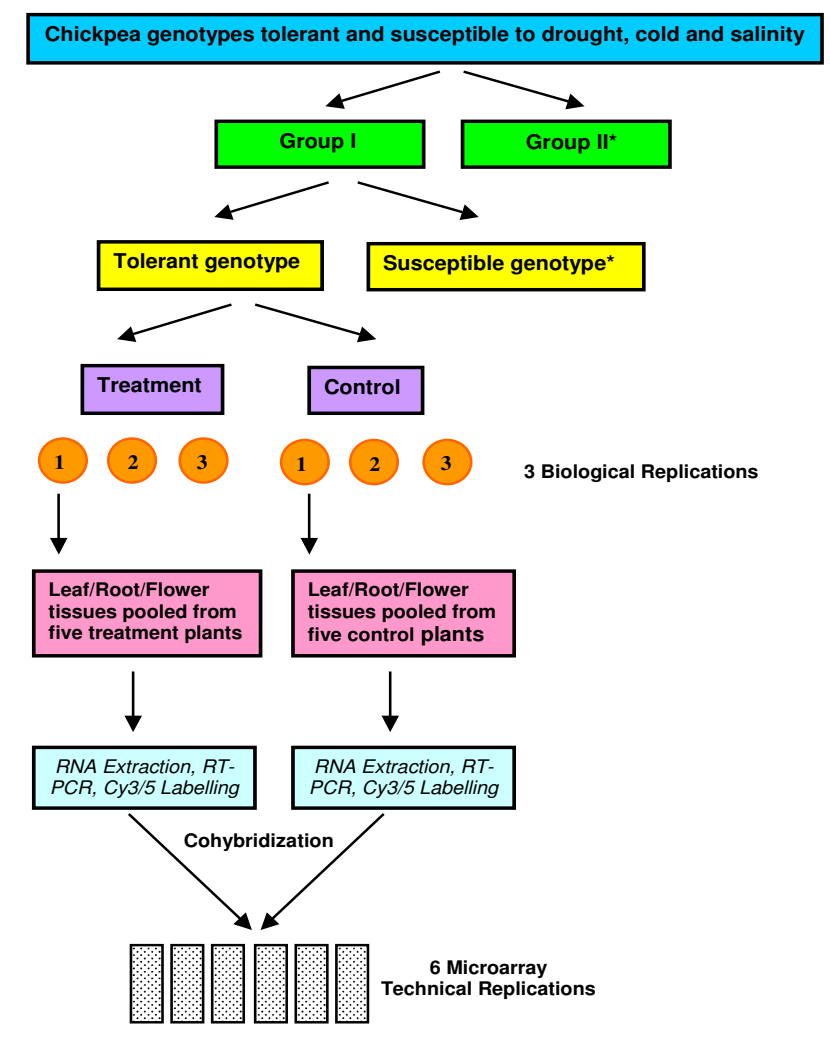

\section{Figure I}

Flow-chart showing the stress treatment procedure. Flow-chart showing the stress treatment procedure. The high-salinity stress treatment also included two time points ( $24 \mathrm{~h}$ and $48 \mathrm{~h}$ ) at which the tissues were harvested. *Group II was processed in the same way as Group I. Susceptible genotypes were challenged and processed in the same way as shown for tolerant genotypes. more transcripts were revealed to be $\mathrm{DE}$ by drought stress (desiccation), followed by high-salinity stress $(250 \mathrm{mM}$ $\mathrm{NaCl})$ and cold stress $\left(4^{\circ} \mathrm{C}\right)[29]$. However,also in Arabidopsis, [34] found more transcripts to be DE in response to cold stress $\left(4^{\circ} \mathrm{C}\right)$, followed by high-salinity $(100 \mathrm{mM}$ $\mathrm{NaCl}$ ) and osmotic/drought stress (200 mM Mannitol). Therefore, we propose that the number of DE transcripts in response to a particular stress depends on the method of stress induction and its severity. In this study, the lower number of $\mathrm{DE}$ transcripts in response to drought stress may be attributed to the nature of drought stress imposed, where pots were allowed to slowly lose water (5-10\% water content/day) over a period of 8 days. This mimicked drought-stress but was relatively less severe than the cold or high-salinity stress treatments. Perhaps more DE transcripts may have been identified if the plants were held at $30 \%$ pot water content for a longer period. For all treatments, the number of undetected microarray probes (mean fluorescence intensity less than two times the mean local background intensity in all tissue-types and replications) in each chickpea genotype varied according to the source of the probes. In general, the levels of undetected features for $L$. sativus probes were higher than the $C$. arietinum probes.

None of the lentil RGA probes were detected in any treatment or genotype, possibly due to hybridization interference caused by introns present in these genomic DNA probes. Similar results were obtained [33] using the same probes for expression profiling of Ascochyta blight response in chickpea. The transcripts DE in response to drought, cold and high-salinity stresses included those associated with aquaporins, dehydrins, membranerelated proteins, senescence-associated proteins, superoxide dismutases, protein kinases, proline oxidase, trehalose phosphatase, phosphate-induced protein, and ubiquitins that have been previously implicated to be responsive to these stresses [44-49]. Considering the large number of DE transcripts identified for each stress, only those transcripts thought to be potentially functionally important will be focused upon ' [see Additional file 1; Additional file 2; Additional file 3]'.

\section{Drought stress response}

Due to the poor quality and yield of RNA from root samples, only leaf and flower tissues were used for analysis of drought stress response. Six microarrays were hybridized for each of the 48 genotype $\times$ treatment/control $\times$ tissuetype $\times$ biological replication conditions, producing 288 microarray images for analysis of DE transcripts. Globally, the number of repressed transcripts was higher than those induced across all the genotypes and tissue types studied (Table 2). Tolerant genotypes shared a similar number of induced transcripts but tolerant-2 (BG 362) had twice the number of repressed transcripts than tolerant-1 (BG 


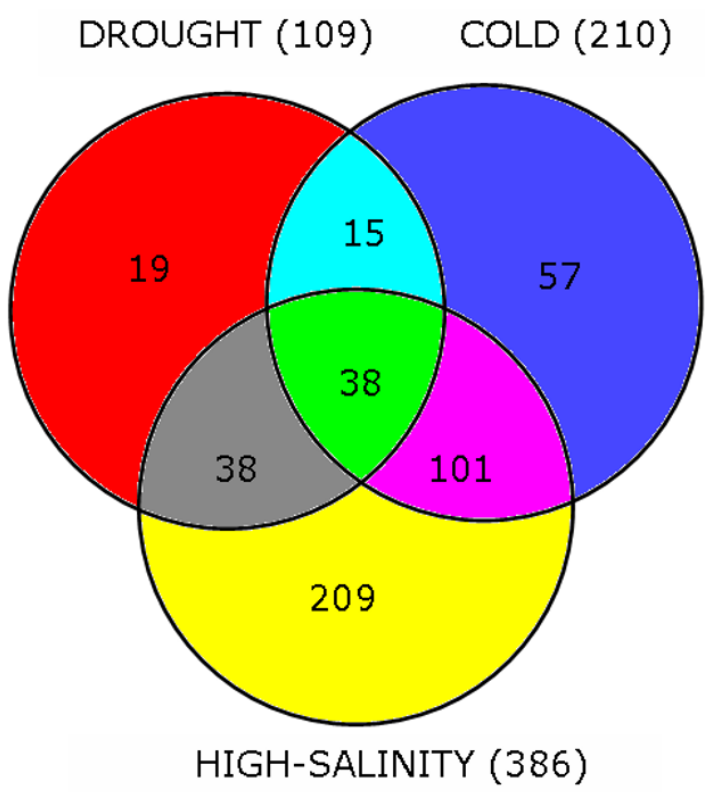

Figure 2

Relationship between the number of DE transcripts in amongst the three abiotic stress treatments. Combined relationship between the number of DE transcripts in amongst the three abiotic stress treatments for all genotypes, tissue types and time-points.

1103). The susceptible-1 (Kaniva) genotype induced thrice the number of transcripts induced by susceptible- 2 (Genesis 508), but both susceptible genotypes repressed the same number of transcripts. The DE transcripts in response to drought stress coded for various functional and regulatory proteins, most of which were repressed. Protein and other solute transport was repressed in susceptible- 1 flowers but induced in tolerant- 2 flowers. This was evidenced by the induction of a protein-transport facilitation protein (DY475074) in flowers of tolerant-2 and repression of aquaporin-like membrane channel protein (DY396334) and DNA-J like protein involved in intracellular protein transport (DY475488) in flowers of susceptible-1. Two putative auxin-repressed proteins (DY396289, DY396359) were highly repressed in flowers and leaves of tolerant-2 but were induced in flowers and leaves of susceptible-1. The plant hormone auxin regulates growth and development processes by controlling the expression of auxin-responsive genes, for example, by down-regulating auxin-repressive genes to effect growth [50]. Subsequently, the down-regulation of this gene in the tolerant genotype and up-regulation in susceptible genotype may indicate that the susceptible genotype had ceased growth due to the drought stress while the tolerant genotype was able to continue normal growth. Further, auxin-repressible genes have cis-elements responsive to sucrose in their promoter regions and are regulated by sucrose [50]. The sucrose-responsive transcription factor (DY475375) in this study was induced in the flowers of tolerant-2 where the auxin-repressed protein was repressed. Therefore, it may be hypothesised that sucrose plays a key role in the drought-stress response of tolerant2.

Defence-related genes including pathogenesis-related proteins (DY396305 and DY396343), nematode-resistance protein ( $\underline{\mathrm{CV} 793603}$ ), Cf-9 gene cluster (DY396352) and disease resistance response proteins (DY396265 and DY396276) were repressed in flowers of tolerant and susceptible genotypes. Alternatively, pea disease resistance response protein (DY396390) and a multi-resistance protein $A B C$ transporter (CV793605) were induced in flowers of both tolerant genotypes. Disease resistance proteins have been shown to be expressed in response to abiotic stresses [25], but their exact role remains unknown. Some genes involved in energy metabolism (DY396279 and DY475316) were repressed in leaves and flowers of tolerant and susceptible genotypes. The genes involved in photosynthesis were repressed in shoots following the treatment of plants with $\mathrm{NaCl}$ (salt stress), PEG (osmotic stress) or ABA. This response is consistent with the closure of stomata in response to high ABA or osmotic stress, inhibition of $\mathrm{CO}_{2}$ fixation, and a reduced need for energy capture by photosynthesis [25]. Interestingly, two cytosolic fructose 1,6-bisphosphatase transcripts involved in cellular metabolism were repressed only in flowers of both susceptible genotypes. Fructose 1,6-bisphosphatase is involved in gluconeogenesis and is subject to indirect regulation by ATP. When the concentration of ATP in the cell

Table 2: Number of > 2-fold differentially expressed transcripts for each genotype and stress. The details on transcripts $>2$-fold induced or repressed are presented in Additional files I, 2 and 3

\begin{tabular}{|c|c|c|c|c|c|}
\hline \multirow[t]{2}{*}{ Condition } & \multirow[t]{2}{*}{ Genotype } & \multicolumn{4}{|c|}{ Number of Transcripts } \\
\hline & & \multicolumn{2}{|c|}{ Induced } & \multicolumn{2}{|c|}{ Repressed } \\
\hline \multicolumn{6}{|l|}{ Drought } \\
\hline Tolerant- I & BG 1103 & \multicolumn{2}{|c|}{6} & \multicolumn{2}{|c|}{21} \\
\hline Tolerant-2 & BG 362 & \multicolumn{2}{|c|}{7} & \multicolumn{2}{|c|}{45} \\
\hline Susceptible-I & Kaniva & \multicolumn{2}{|c|}{6} & \multicolumn{2}{|c|}{20} \\
\hline Susceptible-2 & Genesis 508 & \multicolumn{2}{|c|}{2} & \multicolumn{2}{|c|}{21} \\
\hline \multicolumn{6}{|l|}{ Cold } \\
\hline Tolerant-I & Sonali & \multicolumn{2}{|c|}{17} & \multicolumn{2}{|c|}{45} \\
\hline Tolerant-2 & ILC 01276 & \multicolumn{2}{|c|}{ II } & \multicolumn{2}{|c|}{59} \\
\hline Susceptible-I & Amethyst & \multicolumn{2}{|c|}{60} & \multicolumn{2}{|c|}{43} \\
\hline Susceptible-2 & DOOEN & \multicolumn{2}{|c|}{18} & \multicolumn{2}{|c|}{33} \\
\hline High-salinity & & $24 \mathrm{hpt}$ & $48 \mathrm{hpt}$ & $24 \mathrm{hpt}$ & $48 \mathrm{hpt}$ \\
\hline Tolerant-I & CPI 060546 & 10 & 33 & 103 & 70 \\
\hline Tolerant-2 & ICC 06474 & 23 & 7 & 85 & 65 \\
\hline Susceptible-I & CPI 60527 & 23 & 50 & 40 & 111 \\
\hline Susceptible-2 & ICC 08161 & 10 & 7 & 64 & 62 \\
\hline
\end{tabular}


is low, AMP would then be high which in turn inhibits fructose 1,6-bisphosphatase and thus gluconeogenesis. Subsequently, at low ATP concentration the cell does not consume energy for synthesizing glucose. Therefore, the susceptible genotypes may be lacking ATP as a result of the drought stress. Additionally, some transcripts related to senescence, including auxin responsive protein IAA9 (DY396315), senescence-associated protein DIN 1 (DY396338), and dehydration stress-induced protein (DY396321) were repressed in leaves and flowers of the tolerant genotypes, which may also be indicative of drought tolerance.

\section{Cold stress response}

Six microarrays were hybridized for each of the 48 genotype $\times$ treatment/control $\times$ tissue-type $\times$ biological replication conditions, producing 288 microarray images for analysis of DE transcripts. The susceptible-1 (Amethyst) genotype had the highest number of induced transcripts (Table 2), whilst tolerant-2 (ILC 01276) had the highest number of repressed transcripts. The susceptible-1 genotype was unique as it showed more induced transcripts than repressed. The number of DE transcripts in response to cold stress was approximately double than that observed for drought stress. The DE transcripts fell into various functional categories, which indicated a broad response. Important transcripts included an auxinrepressed protein (DY475078) and auxin responsive protein IAA9 (DY396315) that are involved in cell rescue and were induced in flowers and leaves of both susceptible genotypes. The induction of auxin-repressible proteins is known to be negatively correlated with shoot elongation [50], thus this observation may indicate that the growth and development of cold susceptible genotypes was repressed due to the cold-stress. Interestingly, two phosphate-induced proteins (DY475076 and DY475172) were induced in flowers/pods of tolerant-1 (Sonali). Phosphorus is important for improved flower formation and seed production, as well as earlier crop maturity [51]. This result may imply that the tolerant genotype was able to sustain flowers/pods under cold stress condition.

Interestingly, beta-glucosidase (DY475415) and betagalactosidase (EB085056 and DY475141) transcripts were repressed in leaves of both tolerant genotypes. These enzymes are hydrolases that catalyse the reactions associated with hydrolysis of disaccharides (e.g. sucrose) into monosaccharides. Therefore, the tolerant genotypes appeared to be retaining disaccharides under cold stress. Further, sucrose synthase (DY475105) was induced in leaves of tolerant-1, which supports an accumulation of sucrose. Importantly, the microorganisms Escherichia coli and Bacillus thuringiensis show increased tolerance to freeze drying in the presence of disaccharides such as sucrose, and it has been proposed that they protect mem- branes and proteins in intact bacteria while drying [52]. Potentially, these molecules may perform a similar role in plant cells and provide protection against cold stress. Additionally, S-adenosylmethionine decarboxylase (DY475170) transcript was induced in flowers and leaves of susceptible- 1 and flowers of tolerant- 2 and is known to be involved in the synthesis of polyamines that act as osmolytes and accumulate under drought/osmotic stress [53].

A gluthatione S-transferase (GST) transcript (DY396404) was induced in leaves of susceptible-1 while another GST (DY475250) was repressed in leaves of tolerant-2. GST is believed to act as antioxidant enzyme to help scavenge reactive oxygen species during stress [29]. In Arabidopsis, two GST transcripts were induced and three were repressed in response to drought, cold and salinity [29], which indicates the variable activity of these transcripts under stress perhaps providing an array of functions in the response. Almost all the transcripts involved in energy metabolism/photosynthesis were repressed in leaves and flowers of tolerant and susceptible genotypes (e.g. DY475423， DY475554， DY475555， DY475487， DY475316，DY475556，DY475287，DY475434 and DY475305). This observation is not surprising since low temperature is known to cause reduced enzyme activity, which leads to impairment of photosynthesis and respiration $[54,55]$. Besides these, many transcripts involved in pathogen defence were induced/repressed in leaves and flowers of tolerant and susceptible genotypes (e.g. CV793610， DY396305, DY396390， DY475397, DY396269 and DY396359). Although defence related genes have been shown to be expressed in response to abiotic stresses [29], their actual role still remains unclear. Finally, the proteins with unknown and unclear functions that were repressed in leaves and flowers of tolerant and susceptible genotypes need further investigation to confirm their involvement and role in stress response.

\section{High-salinity stress response}

Six microarrays were hybridized for each of the 96 genotype $\times$ treatment/control $\times$ tissue-type $\times$ time-point $\times$ biological replication conditions, producing 576 microarray images for analysis of DE transcripts. The tissues from 24 hpt and 48 hpt were analysed separately but, overall, the number of transcripts repressed were higher than those induced for all genotypes, tissue types and time points (Table 2). Tolerant-1 (CPI 060546) had the highest number of repressed transcripts at $24 \mathrm{hpt}$ while susceptible-1 (CPI 60527) and tolerant-2 (ICC 06474) had the highest number of induced transcripts. At $48 \mathrm{hpt}$, susceptible- 1 had highest number of induced and repressed transcripts. The number of DE transcripts detected for highsalinity stress was much higher than for both cold and drought stresses. Transcripts of interest included two poly 
(A) binding protein transcripts (DY396360 and DY396412) that were repressed in roots of both tolerant genotypes at $24 \mathrm{hpt}$, whilst at $48 \mathrm{hpt}$ these transcripts were induced in roots and repressed in shoots of susceptible-1. Poly (A) binding proteins are a family of eukaryotic, cytoplasmic proteins thought to bind to the poly (A) tails of mRNAs and play a role in translational regulation [56]. In Arabidopsis, one RNA-binding protein was induced and three RNA-binding proteins repressed in response to drought, cold and high-salinity [29]. Interestingly, a splicing factor-like protein (DY396290) involved in DNA processing was repressed in roots of both tolerant genotypes at $24 \mathrm{hpt}$, and also repressed in shoots and roots of both susceptible genotypes at $24 \mathrm{hpt}$. However, at $48 \mathrm{hpt}$ it was repressed only in roots of both susceptible genotypes. Subsequently, at $24 \mathrm{hpt}$, RNA production/processing may be restricted in roots/shoots of all genotypes but is repressed only in roots of susceptible genotypes at 48 hpt.

A putative heat shock protein and heat shock factor binding protein (DY396361 and DY475474) were repressed in roots and shoots of both tolerant genotypes at $24 \mathrm{hpt}$. On the contrary, the heat shock protein DNA-J homolog (DY396397) was induced in roots of susceptible-1 at 24 hpt. Further, these transcripts were repressed in roots of all tolerant and susceptible genotypes at $48 \mathrm{hpt}$. Heat shock proteins are molecular chaperones for protein molecules and play an important role in protein-protein interactions such as folding, assisting in the establishment of proper protein shape and prevention of unwanted protein aggregation. In other plants these proteins are induced by abiotic stresses like drought, cold and high-salinity $[29,34]$. Several of the heat shock proteins studied [29] like, HSP 90 and HSP 81-2, were repressed at 10- and 24-hpt after being induced in the first hour, thus the heat-shock proteins in this study may have been induced very early after high-salinity treatment and then repressed at the tissue sampling times. Interestingly, a proline oxidase (DY475225) transcript involved in the conversion of proline to glutamate was repressed only in roots of the susceptible genotypes at $24 \mathrm{hpt}$, and repressed in shoots and roots of susceptible-2 and in shoots of tolerant- 2 at 48 hpt. Osmolytes such as proline accumulate under salt stress to prevent wilting and toxicity in the presence of high internal salt concentration and possibly aid in stress tolerance [36]. These osmolytes usually accumulate if the plants cannot maintain turgor by regulating ion exchange. Subsequently, the early repression of proline oxidase in susceptible genotypes may indicate a reaction to osmotic stress through the retention of proline, which was only observed later in one tolerant genotype.

Transcripts representing a senescence-associated protein (DY396273) and senescence associated protein DIN 1
(DY396338) were repressed in roots of tolerant-1 at 24 hpt, whilst ripening related protein (DY396347) was repressed in its shoot at this time. However, DY396338 was induced in roots of susceptible- 1 at the same timepoint, and DY396273 was induced in shoots of susceptible- 1 at 48 hpt. These results may indicate that whilst the tolerant-1 genotype was avoiding ageing/death related genes, the susceptible- 1 genotype was already undergoing cell death due to high-salinity stress at $24 \mathrm{hpt}$ in roots and 48 hpt in shoots. Two cytosolic fructose 1,6-bisphosphatase transcripts (DY475548 and DY475543) were repressed only in roots of the tolerant genotypes at $24 \mathrm{hpt}$, but DY475543 was repressed in roots of susceptible genotypes at $48 \mathrm{hpt}$. As described earlier, fructose 1,6-bisphosphatase is involved in gluconeogenesis and is under indirect regulation of ATP. Thus, the roots of tolerant genotypes may be conserving energy by repressing this enzyme as early at $24 \mathrm{hpt}$, while this did not occur in the susceptible genotypes until $48 \mathrm{hpt}$, which may contribute to susceptibility.

Among the defence-related transcripts, caffeoyl-CoA Omethyltransferase 4 (DY396415), which is associated with lignification [57], was repressed in shoots and roots of both susceptible genotypes at $24 \mathrm{hpt}$, and repressed only in shoots of susceptible- 1 at $48 \mathrm{hpt}$. Lignin biosynthesis is related to the reinforcement of the plant cell wall in the response to wounding or pathogen challenge. On the other hand, a putative glycine-rich cell wall protein GRP 1.8 (DY396342) was repressed only in the roots of the tolerant genotypes at $24 \mathrm{hpt}$. GRPs are also closely associated with lignification of cell walls in response to wounding or pathogen attack [58]. Thus, the repression of genes related to lignification in both susceptible and tolerant genotypes may indicate the direction of cellular resources toward other processes. Interestingly, several pathogenesis related protein 4A transcripts (DY396281, DY396372，DY396384，DY396388， CV793597) were induced in the roots of all tolerant and susceptible genotypes at $24 \mathrm{hpt}$, and again at in all genotypes except susceptible- 2 at 48 hpt. Plant defence related genes have been known to be induced in response to abiotic stresses [29]. In fact, many genes identified in expression studies in response to salt stress include those in common with pathogen infection [36]. Considering that pathogenesis related protein $4 \mathrm{~A}$ transcripts were highly induced only in response to high-salinity stress in this study, further investigation of their involvement in salt stress may be warranted.

An interesting pattern was observed amongst the transcripts related to signalling and communication. A putative histidine-containing phospho-transfer protein ATHP3 (DY396300) and a protein kinase (DY475077) were repressed only in roots of both tolerant genotypes at 
$24 \mathrm{hpt}$, whilst ATHP3 was repressed only in roots of tolerant- 2 and protein kinase was repressed in shoots of tolerant- 1 at 48 hpt. The ATHPs (or AHPs) are thought to be involved in stress sensing and relay signal transduction, where ATHP1 is thought to sense osmotic stress and transfer the signal via ATHP2/ATHP3 to the Arabidopsis Response Regulators (ARRs) [59]. The protein kinases are also thought to be involved in various signalling cascades related to stress responses [60]. Thus, the repression of these signalling molecules only in tolerant genotypes may have significance and needs further investigation. Putative auxin-repressed proteins (DY396269, DY396289, DY396292 and DY396359) were induced in roots of tolerant-1, tolerant-2 and susceptible-1 whilst they were repressed in shoots of tolerant- 2 and susceptible- 1 at 48 hpt. Auxin regulates growth and development and the induction of auxin-repressible proteins is negatively correlated with shoot elongation [50]. This observation suggests that the roots of all genotypes ceased to develop 48 hpt but the shoots were still undergoing growth, which supports the hypothesis that genes regulating cell division and elongation might be affected by salt stress [36].

Transcripts associated with transport facilitation like aquaporin (DY475124) and aquaporin-like transmembrane protein (DY396334) were repressed in roots of the tolerant genotypes at $24 \mathrm{hpt}$. Also, aquaporin 2 (integral tonoplast water channel protein; DY475512), aquaporin membrane protein (DY475174) and aquaporin-like transmembrane channel protein (DY396334) were repressed in roots of susceptible- 1 at $48 \mathrm{hpt}$. At the same time only DY475174 was repressed in roots of tolerant- 1 . Changes in expression of aquaporins (water-channel proteins) are common to other salt stress studies and may be due to shrinkage of cells and organelles after osmotic stress [36]. Finally, many genes with unknown/unclear functions were induced/repressed in shoots and roots of all the genotypes and most of the transcripts associated with energy metabolism were repressed in all genotypes and conditions.

\section{Consensus stress-responsive transcripts}

The main objective of this study was to identify transcripts that were consistently DE between tolerant and susceptible genotypes for each stress. Our hypothesis was that if a putative gene was consistently expressed only in tolerant or susceptible genotypes for a particular stress, it might be a candidate for tolerance/susceptibility to the stress. Of the 109 DE transcripts expressed in drought tolerant and susceptible genotypes, only two were consistently expressed (Table 3). These included a cytosolic fructose 1,6-bisphosphatase (DY475548) and a gene with unknown function, which were repressed in flowers of both susceptible genotypes. Fructose 1,6-bisphosphatase is repressed when cellular ATP levels are low to conserve energy, which may be an effect of drought susceptibility. The involvement and role of genes with unknown function have to be confirmed by additional studies.

Fifteen out of the 210 DE transcripts found in cold tolerant and susceptible genotypes were consistently expressed (Table 3), all of which were repressed. Most of the putative genes were identified in leaves of the tolerant genotypes, and included a beta-galactosidase (DY475141) transcript that was described earlier as possibly indicative of disaccharide (e.g. sucrose) retention with the effect of protecting cell membranes during cold stress. Several protein synthesis/modification and energy/metabolism transcripts were also repressed (e.g. DY475282, DY396371 and DY475555), which was likely due to the impairment of photosynthesis and respiration at low temperature $[54,55]$. Other consistently repressed transcripts in tolerant genotypes included putative signalling (DY396262, DY475384 and DY396307) and defence-related proteins (CV793589 and DY396343), which may be involved in the repression of cell death mechanisms. In susceptible genotypes, a putative superoxide dismutase precursor protein (DY475397) and sorting nexin protein (DY475523) were the only known transcripts to be consistently repressed. Superoxide dismutase is involved in the programmed cell death pathway where its repression allows the accumulation of reactive oxygen species that signal and contribute to cell death [61]. Subsequently, this result suggests that cold stress in susceptible genotypes may lead to the promotion of cell death pathways.

Of the transcripts consistently expressed in tolerant genotypes in response to high-salinity stress, the annotation of transcripts at $24 \mathrm{hpt}$ suggest a reduction in energy production in shoots and roots by repression of putative genes including P700 chlorophyll a-apoprotein (DY475501) and NADH-plastoquinone oxidoreductase subunit I (DY475287), cytosolic fructose 1,6-bisphosphatase (DY475548) and splicing factor-like protein (DY396290). These observations may indicate that the available cellular resources have instead been deployed to maintain the ionic balance needed to tolerate the highsalinity conditions. The ATHP3 (DY396300) and protein kinase (DY475077) are potentially involved in signalling cascades responsible for sensing and relaying osmotic stress signals, but their consistent repression in tolerant genotypes suggest that they may negatively regulate the genes responsible for signalling high-salinity tolerance. Additionally a glycine rich protein (DY396342) that is associated with lignification of cell walls in response to wounding and pathogen attack was repressed in tolerant genotypes, which indicates that a reduction of lignin deposition may be an effect of high-salinity tolerance. In tolerant genotypes at $48 \mathrm{hpt}$, two energy and metabolicrelated transcripts were consistently repressed, including a 
Table 3: List of transcripts that were consensually differentially expressed amongst the tolerant and susceptible genotypes for each stress, tissue type and time-point

\begin{tabular}{|c|c|c|c|c|c|}
\hline \multirow[t]{2}{*}{ GenBank Accession } & \multirow[t]{2}{*}{ Putative function } & \multicolumn{2}{|c|}{$\log _{2}$ ratio } & \multicolumn{2}{|c|}{$P$ value } \\
\hline & & Group I* & Group II* & Group I* & Group II* \\
\hline \multicolumn{6}{|l|}{ Drought susceptible flowers } \\
\hline DY475548 & $\begin{array}{l}\text { Cytosolic fructose 1,6- } \\
\text { bisphosphatase }\end{array}$ & -1.7 & -1.02 & $4.8 \mathrm{IE}-43$ & $7.33 \mathrm{E}-13$ \\
\hline DY47505I & Unknown & -1.47 & -5.24 & $1.29 \mathrm{E}-\mathrm{II}$ & $7.45 \mathrm{E}-40$ \\
\hline \multicolumn{6}{|l|}{ Cold tolerant leaves } \\
\hline DY475555 & $\begin{array}{l}\text { Chlorophyll a/b binding } \\
\text { protein }\end{array}$ & -1 & -1.89 & $7.65 \mathrm{E}-12$ & $1.90 \mathrm{E}-03$ \\
\hline EB085047 & I8S rRNA & -1.25 & -1.15 & 8.04E-05 & I.0IE-05 \\
\hline DY396262 & $\begin{array}{l}\text { Probable Ca-binding } \\
\text { mitochondrial carrier }\end{array}$ & -1.1 & -1.6 & $2.82 \mathrm{E}-\mathrm{II}$ & 3.97E-03 \\
\hline DY475384 & $\begin{array}{l}\text { Serine/threonine protein } \\
\text { kinase }\end{array}$ & -2.43 & -3.27 & $1.19 \mathrm{E}-18$ & 1.33E-08 \\
\hline DY475I4I & Beta-galactosidase & -2 & -1.63 & $1.35 \mathrm{E}-05$ & $2.98 \mathrm{E}-04$ \\
\hline DY39637I & Polyubiquitin & -1.05 & -1.62 & $2.62 \mathrm{E}-08$ & $7.42 \mathrm{E}-04$ \\
\hline DY475282 & Trehalose-phosphatase & -1.27 & -1.82 & $2.94 \mathrm{E}-04$ & 3.49E-05 \\
\hline DY396343 & $\begin{array}{l}\text { Pathogenesis-related } \\
\text { protein }\end{array}$ & -1.46 & -1.69 & I.05E-II & 3.27E-06 \\
\hline DY396307 & $\begin{array}{l}\text { Serine/threonine protein } \\
\text { kinase }\end{array}$ & -1.12 & -1.14 & $1.93 \mathrm{E}-18$ & $4.64 \mathrm{E}-03$ \\
\hline DY475323 & Unclear & -1.42 & -2.05 & $2.53 \mathrm{E}-05$ & $2.84 \mathrm{E}-28$ \\
\hline DY475203 & Unknown & $-|.5|$ & -1.6 & $4.58 \mathrm{E}-04$ & $3.91 \mathrm{E}-05$ \\
\hline \multicolumn{6}{|l|}{ Cold susceptible leaves } \\
\hline DY475523 & Sorting nexin protein & -2.1 & -1.12 & 6. $18 \mathrm{E}-05$ & $8.43 \mathrm{E}-05$ \\
\hline DY475329 & Unclear & -1.7 & -1.07 & $1.92 \mathrm{E}-05$ & 8.39E-03 \\
\hline DY475431 & Unknown & -1.54 & -1.63 & $8.43 \mathrm{E}-03$ & $3.79 \mathrm{E}-06$ \\
\hline \multicolumn{6}{|l|}{ Cold susceptible flowers } \\
\hline DY475397 & $\begin{array}{l}\text { Superoxide dismutase } \\
\text { copper chaperone } \\
\text { precursor }\end{array}$ & -4.16 & -1.47 & $9.50 \mathrm{E}-07$ & 7.69E-09 \\
\hline \multicolumn{6}{|c|}{ High-salinity tolerant shoot $24 \mathrm{hpt}$} \\
\hline DY47550I & $\begin{array}{l}\text { P700 chlorophyll a- } \\
\text { apoprotein }\end{array}$ & -1.06 & -2.13 & I.06E-03 & $1.13 E-06$ \\
\hline DY475287 & $\begin{array}{l}\text { NADH-plastoquinone } \\
\text { oxidoreductase subunit I }\end{array}$ & -3.55 & -2.41 & $3.75 \mathrm{E}-04$ & $1.53 \mathrm{E}-04$ \\
\hline DY475215 & Unknown & -2.14 & -1.52 & $3.97 \mathrm{E}-07$ & 2.6IE-06 \\
\hline \multicolumn{6}{|c|}{ High-salinity tolerant root $24 \mathrm{hpt}$} \\
\hline EB085052 & Unknown & -1.46 & -1.64 & $3.69 \mathrm{E}-07$ & I.78E-08 \\
\hline DY396290 & Splicing factor-like protein & -1.7 & $-1.3 \mid$ & $1.75 \mathrm{E}-03$ & $1.22 \mathrm{E}-02$ \\
\hline DY396300 & $\begin{array}{l}\text { ATHP3 (histidine- } \\
\text { containing } \\
\text { phosphotransfer protein) }\end{array}$ & -1.3 & -1.21 & $3.40 \mathrm{E}-06$ & $1.24 \mathrm{E}-10$ \\
\hline DY396342 & $\begin{array}{l}\text { Glycine-rich cell wall } \\
\text { protein GRP I.8 }\end{array}$ & -1.43 & -2.77 & $3.5 \mathrm{IE}-03$ & 4.0IE-04 \\
\hline DY475077 & Protein kinase & -1.37 & -2.91 & $2.3 \mathrm{IE}-07$ & $2.13 \mathrm{E}-06$ \\
\hline DY475548 & $\begin{array}{l}\text { Cytosolic fructose I,6- } \\
\text { bisphosphatase }\end{array}$ & -2.36 & -1.22 & $2.10 \mathrm{E}-03$ & $5.54 \mathrm{E}-04$ \\
\hline DY475124 & Aquaporin & -1.73 & -1 & $9.28 \mathrm{E}-13$ & $1.57 \mathrm{E}-13$ \\
\hline DY475256 & Unknown & -1.07 & -1.15 & I.77E-05 & I.3IE-02 \\
\hline DY475275 & Unknown & -1.93 & -1.27 & $2.68 \mathrm{E}-10$ & $3.50 \mathrm{E}-05$ \\
\hline DY475293 & Unknown & 1.23 & $\mathrm{I} .4$ & $4.70 \mathrm{E}-06$ & $8.35 \mathrm{E}-11$ \\
\hline DY475347 & Unknown & -5.82 & -2.72 & $2.49 \mathrm{E}-03$ & $1.58 \mathrm{E}-19$ \\
\hline DY475416 & Unknown & -1.94 & -1.67 & $9.14 \mathrm{E}-03$ & $3.24 \mathrm{E}-04$ \\
\hline \multicolumn{6}{|c|}{ High-salinity susceptible root $24 \mathrm{hpt}$} \\
\hline DY475225 & Proline oxidase & -1.19 & -2.64 & $5.03 \mathrm{E}-04$ & $1.08 \mathrm{E}-08$ \\
\hline DY475186 & Unclear & -2.3 & -1.56 & 4.35E-09 & $1.36 \mathrm{E}-08$ \\
\hline \multicolumn{6}{|c|}{ High-salinity tolerant shoot $48 \mathrm{hpt}$} \\
\hline DY396301 & $\begin{array}{l}\text { Pathogenesis-related } \\
\text { protein }\end{array}$ & -3.26 & -1.73 & $2.87 \mathrm{E}-08$ & $3.30 \mathrm{E}-07$ \\
\hline \multicolumn{6}{|c|}{ High-salinity susceptible shoot 48 hpt } \\
\hline DY475205 & Unclear & 2.49 & 1.45 & $2.18 \mathrm{E}-16$ & $1.63 \mathrm{E}-04$ \\
\hline DY475048 & Unknown & -2.7 & -1.76 & 6.97E-03 & 3.47E-03 \\
\hline \multicolumn{6}{|c|}{ High-salinity tolerant root $48 \mathrm{hpt}$} \\
\hline DY396262 & $\begin{array}{l}\text { Probable Ca-binding } \\
\text { mitochondrial carrier }\end{array}$ & -1.18 & -1.26 & $9.17 \mathrm{E}-15$ & $7.88 \mathrm{E}-03$ \\
\hline DY475403 & Carbonic anhydrase & -1.47 & -2.36 & $5.46 \mathrm{E}-07$ & $2.28 \mathrm{E}-09$ \\
\hline DY475242 & $\begin{array}{l}\text { Thiazole biosynthetic } \\
\text { enzyme }\end{array}$ & -1.77 & -2.48 & $4.38 \mathrm{E}-06$ & $9.27 \mathrm{E}-06$ \\
\hline
\end{tabular}


Table 3: List of transcripts that were consensually differentially expressed amongst the tolerant and susceptible genotypes for each stress, tissue type and time-point (Continued)

\begin{tabular}{|c|c|c|c|c|c|}
\hline DY39628I & $\begin{array}{l}\text { Pathogenesis-related } \\
\text { protein } 4 \mathrm{~A}\end{array}$ & 3.35 & 2.6 & $2.8 \mathrm{IE}-17$ & $3.49 \mathrm{E}-14$ \\
\hline DY475416 & Unknown & -3.71 & -2.25 & $4.30 \mathrm{E}-06$ & $1.80 \mathrm{E}-08$ \\
\hline DY475521 & Unknown & 1.38 & 1.01 & $3.68 \mathrm{E}-09$ & 6.70E-07 \\
\hline \multicolumn{6}{|c|}{ High-salinity susceptible root $48 \mathrm{hpt}$} \\
\hline DY396290 & Splicing factor-like protein & -2.63 & -1.65 & $4.68 \mathrm{E}-08$ & 1.97E-04 \\
\hline DY475408 & Xylosidase & 2.48 & 1.09 & $9.41 \mathrm{E}-04$ & $4.53 \mathrm{E}-03$ \\
\hline DY475217 & Unclear & -2.03 & -1.02 & I.39E-04 & 7.44E-03 \\
\hline DY475390 & Unknown & 2.19 & 1.05 & $2.65 \mathrm{E}-04$ & $1.56 \mathrm{E}-03$ \\
\hline
\end{tabular}

* The tolerant/susceptible genotypes used in Group I and Group II are mentioned in Table 4.

carbonic anhydrase (DY475403) and putative thiazole biosynthetic enzyme (DY475242) in roots, suggesting again the sacrifice of general cellular functions for maintenance of ionic balance. In shoots, only a pathogenesisrelated protein (DY396301) was consistently repressed at $48 \mathrm{hpt}$, but a similar transcript (DY396281) was induced in roots of tolerant genotypes at the same time. As described earlier, PR proteins have been shown to be expressed under abiotic stresses but their role is not very well understood. Subsequently, these putative defencerelated proteins may have a tissue-specific role in conferring high-salinity tolerance in chickpea.

Only two transcripts were DE in susceptible genotypes at $24 \mathrm{hpt}$, all occurring in root tissue. One of these was gene with unclear function and the other a proline oxidase transcript (DY475225) that may indicate the retention of proline, which is an osmolyte known to accumulate under osmotic stresses and plays a role in stabilizing structure of plant proteins [36]. At $48 \mathrm{hpt}$, a putative splicing factorlike protein (DY396290) was consistently repressed in roots of susceptible genotypes, suggesting the potential stress-related repression of RNA production/processing. Interestingly, a putative xylosidase (DY475408) was induced in susceptible roots at $48 \mathrm{hpt}$. Xylosidase exhibits hydrolytic activity towards polysaccharides and is responsible for structural changes by degradation of polysaccharides to allow the modification of the cell wall [62]. Thus, this result shows that susceptible genotypes may undergo cell wall degradation as a result of high-salinity stress. Finally, several unknown/unclear transcripts were DE in both tolerant and susceptible genotypes. Of interest were two unknowns (DY475293 and DY475521) that were consistently induced in tolerant genotypes and may be important for high-salinity tolerance.

\section{Conclusion}

This study revealed that 476 transcripts were DE in all stresses, genotypes, tissue-types, and time points tested. The large number of transcriptome changes observed highlights the difficulty of understanding the global context of stress responses. In Arabidopsis, approximately 30\% of the genome was potentially regulated by salt, cold and osmotic stress [34]. In our study it was also observed that the number of transcripts expressed depended on the type and severity of stress, where more transcripts were expressed under high-salinity followed by cold and drought stress. The DE transcripts between the stressed and unstressed plants were classified in relation to functional categories and, overall, more genes were found to be repressed than induced. The genes that were consistently DE in groups of tolerant and susceptible genotypes for each stress were compiled and interesting observations were made when the DE genes were analysed with respect to their biological role in plants.

The main objective of this study was to identify a suite of putative genes that were consistently expressed in tolerant or susceptible genotypes for each stress condition. To our knowledge, this is the first intensive cDNA microarray study for abiotic stress responses in chickpea. Several candidate genes for tolerance/susceptibility were identified from Table 3, but it is crucial to emphasize that changes in mRNA accumulation may not necessarily correlate with protein/enzyme activity levels [63]. Moreover, when applying stress treatments, the response in the plant may be variable due to the nature of treatment, variation in response by plants, or natural variation between plants [28]. Therefore, it may possibly be ideal to compare expression profiles of recombinant inbred lines (RILs) or near isogenic lines (NILs) that are tolerant and susceptible to these abiotic stresses to reduce background genetic variation amongst the plants. The expression profiles provide starting points for in-depth studies on candidate genes to help prioritize the intensive task of using reverse genetics to assign gene functions [34]. The results of this study should therefore be carefully extrapolated until further indepth studies have been carried out. Nevertheless, the annotation of transcripts with significant fold change and detection of consistently DE transcripts between tolerant and susceptible genotypes strongly suggests that these putative genes have a role in abiotic stress responses. Subsequently, the experimental set-up and downstream analysis methods applied in this study are appropriate for identification of putative stress induced transcripts in chickpea. The identification of novel genes, determination of their expression patterns in response to different stress conditions, and an improved understanding of their 
functions in stress adaptation will provide basic knowledge to design effective engineering strategies for enhancement of stress tolerances.

\section{Methods}

\section{Plant materials and experimental design}

Chickpea genotypes tolerant and susceptible to the abiotic stresses of drought, cold and high-salinity were selected (Dr. B. Redden, 2005, pers. comm.; Dr. H. Clarke, 2005, pers. comm.; Moses Maliro, 2005, pers. comm.) and obtained from the Australian Temperate Field Crops Collection, Horsham, Australia (Table 4). Two groups of a tolerant and susceptible genotype were screened to generate an expression profile in response to each abiotic stress. The stress treatments were performed on the tolerant and susceptible genotypes in three biological replications. The experiments were conducted in reference design where respective tissues from unstressed plants served as control. The genes expressed by the two tolerant and susceptible genotypes (for each stress/tissue-type/time-point) were compared in a two-way comparison to reveal genes that were consistently expressed only in the tolerant/susceptible accessions.

\section{Drought stress treatments}

The drought tolerant and susceptible genotypes (five treatment and five control plants per genotype) were cultivated (one plant per $15 \mathrm{~cm}$ pot) in sterile potting mix in a glasshouse at $15-25^{\circ} \mathrm{C}$. All plants were watered to keep the soil moist but excess watering was avoided. The plants were fertilized twice with urea during establishment and once with Nitrosol ${ }^{\circledast}$ (Amgrow, Australia) 45 days after sowing. The drought stress was imposed two weeks after flowering as follows: All plants were saturated with water late in the evening, and the following morning pots were bagged so that no water was allowed to evaporate. A 1.0 $\mathrm{ml}$ pipette tip was cut slightly at the tip and inserted in the pot to allow addition of water. The initial pot weight was recorded. The water content in each pot was estimated to be $30 \%$ of the initial pot weight (based on wet weight and dry weight). From the subsequent day onwards, the con-

Table 4: List of abiotic stress tolerant and susceptible genotypes used in two groups of stress experiments. Genotypes are listed by common name and Australian Temperate Crop (ATC) identification number

\begin{tabular}{lll}
\hline Characteristic & Group I & Group II \\
\hline Drought tolerant & BG II03 (ATC 48III) & BG 362 (ATC 48I04) \\
Drought susceptible & Kaniva (ATC 40030) & Genesis 508 (ATC 45226) \\
Cold tolerant & Sonali (ATC 48II3) & ILC 0I276 (ATC 4002I) \\
Cold susceptible & Amethyst (ATC 4233I) & DOOEN (ATC 40874) \\
Salt tolerant & CPI 060546 (ATC 40586) & ICC 06474 (ATC 40I7I) \\
Salt susceptible & CPI 60527 (ATC 40033) & ICC 08I6I (ATC 40707)
\end{tabular}

* The tolerant/susceptible genotypes used in Group I and Group II are mentioned in Table 4. trol pots were maintained at $80 \%$ water content and the treatment pots were allowed to lose $5-10 \%$ of their water content per day and any extra water lost (>10\%) was replenished. The leaf, root and flower/bud tissues were collected separately when the treatment pots reached $30 \%$ water content, indicative of a drought or high water deficit condition [64] (Dr. V. Vincent, 2005, pers. comm.; Dr. D. Hoisington, 2005, pers comm.). The tissues from the control plants were also collected at this time. All tissues were snap frozen in liquid nitrogen and preserved at $-80^{\circ} \mathrm{C}$ until RNA extraction.

\section{Cold stress treatments}

The cold tolerant and susceptible genotypes (five treatment and five control plants per genotype) were cultivated as described for the drought stress treatment until the cold stress treatment commenced two weeks after flowering. To simulate cold stress, treatment plants were exposed to a $12 \mathrm{~h}$ day $/ 12 \mathrm{~h}$ night temperature cycle of $15-$ $25^{\circ} \mathrm{C}$ and $5^{\circ} \mathrm{C}[38,65]$ (Dr. H. Clarke, 2005, pers comm.). The control plants were maintained in glasshouse conditions $\left(15-25^{\circ} \mathrm{C}\right)$. The leaf and flowers/buds/immature pod tissues from treatment plants were collected after the seventh night at $5^{\circ} \mathrm{C}$. The tissues from the control plants were also collected at this time and all tissues were snap frozen in liquid nitrogen and preserved at $-80^{\circ} \mathrm{C}$ until RNA extraction.

\section{High-salinity stress treatments}

The high-salinity tolerant and susceptible genotypes were cultivated in a hydroponic system using 50 L plastic crates. Two crates were set-up, one each for treatment and control. Forty holes $(8 \times 5$ grid $)$ of $5 \mathrm{~cm}$ diameter were drilled in the crates' lid and rock wool plugs were placed in them. Ten pre-germinated seeds per tolerant and susceptible genotype were transplanted in alternate plugs within each crate. The seedlings were watered normally from above for four days. The following day, the crates were filled with $0.5 \times$ modified Hoagland's nutrient medium ( $\mathrm{pH} 6.5$ ) [66]. The medium was aerated using two aquarium pumps per crate. The nutrient medium was subsequently replaced with $1.0 \times$ Hoagland's solution $(\mathrm{pH}$ 6.5) after a further seven days. At day 18 , the nutrient medium for the treatment plants was replaced with $1.0 \times$ modified Hoagland's with $150 \mathrm{mM}$ Sodium Chloride ( $\mathrm{NaCl})(\mathrm{pH} 6.5)$, which represented a salinity concentration known to be toxic to chickpea [6] (unpublished data). The control plants continued to grow in replaced $1.0 \times$ modified Hoagland's solution ( $\mathrm{pH}$ 6.5). Leaf/shoot and root tissues were collected from five treatment plants at 24 and $48 \mathrm{~h}$ post-treatment (hpt). The tissues from control plants were also collected at these times. The tissues were snap frozen in liquid nitrogen and preserved at $-80^{\circ} \mathrm{C}$ until RNA extraction. 


\section{Microarray construction, target preparation and hybridization}

Microarrays were constructed in accordance with MIAME guidelines [67], following the method of [33]. The 768feature microarrays consisted of 559 chickpea cDNAs, 156 grasspea cDNAs, 41 lentil resistance gene analogs (RGAs) and 12 controls. A complete description of the microarray features can be found. ' [see Additional file 4]'. Printed microarrays were pre-hybridized by blocking in $5 \times \mathrm{SSC}$, $0.1 \%$ SDS, $25 \%$ formamide, $1 \%$ BSA for $45 \mathrm{~min}$ at $42{ }^{\circ} \mathrm{C}$, rinsed in distilled water and dried. Total RNA was extracted from separately pooled tissue samples for each treatment, followed by labeling and hybridization to microarray slides according to [33]. Dye swap was performed in one of the three biological replicates.

\section{Scanning and data analysis}

Slides were scanned and images captured as described [33]. Data transformations consisted of a local background correction, omitting flagged spots, normalization by applying the LOWESS algorithm [68], creating a Cy5/ Cy3 mean signal ratio, $\log _{2}$ conversion, and combining replicates. To identify differentially expressed (DE) genes, expression ratio results were filtered to eliminate genes whose 95\% confidence interval for mean fold change (FC) did not extend to 2-fold up or down. These cut-offs translated into induced transcripts having a $\log _{2}$ ratio $\geq$ 1.0 and repressed transcripts a ratio of $\leq-1.0$. This was followed by a Students $t$ test and False Discovery Rate (FDR) multiple testing correction to retain only genes in which expression changes $v$. unstressed control were significant at $\mathrm{P}<0.05$. High data quality and reproducibility was achieved using five experimental replicates (five stressed and five unstressed plants), three biological replicates and six technical replicates for all microarray spots. Data quality was also improved by the inclusion of negative controls and a dye-swap for one biological replicate.

\section{Quantitative Reverse -Transcription PCR (qRT-PCR)}

The microarray expression results were validated by performing qRT-PCR on a set of selected DE transcripts. This set was chosen to represent different stresses, genotypes, tissue-types, time points and expression values (up/downregulation). The PCR primers were designed using Primer3 [69] and had a GC content of 40-60\%, a Tm > $50^{\circ} \mathrm{C}$, a primer length 20-25 nucleotides, and an expected amplicon size was $100-250 \mathrm{bp}$. The comparative Ct method of quantitation was used with the Actin gene (DY475300) as a reference. The relative fold-change for each of the selected genes was detected from both the tolerant/susceptible genotypes. For each genotype, $5 \mu \mathrm{g}$ total RNA from one of the biological replicates was converted into cDNA using oligodT 15-mer (Roche Diagnostics, Mannheim, Germany) and Superscript II reverse transcriptase (Invitrogen Life Technologies, Carlsbad, CA).
This cDNA was purified using the Qiaquick PCR purification kit (Qiagen, Valencia, CA) and diluted to $250 \mu \mathrm{L}$ in sterile water. Validation experiments were performed on 5 to 6 log dilutions of each of the target genes together with the Actin reference to determine if the amplification efficiencies were equal. Triplicate qRT-PCR reactions were performed using $\mathrm{iQ}^{\mathrm{TM}} \mathrm{SYBR}^{\circledR}$ Green Supermix (Bio-Rad, Hercules, CA), $0.4 \mu \mathrm{M}$ of forward and reverse primers and the required amounts of cDNA template. The PCRs were performed in a Bio-Rad MyiQ ${ }^{\mathrm{TM}}$ thermocycler (Bio-Rad, Hercules, CA). The temperature regime used was $95^{\circ} \mathrm{C}$ for $10 \mathrm{~m}$ followed by 40 cycles of $30 \mathrm{~s}$ at $95^{\circ} \mathrm{C}, 45 \mathrm{~s}$ at $55^{\circ} \mathrm{C}$ and $45 \mathrm{~s}$ at $72^{\circ} \mathrm{C}$. Melting curve analysis by applying increasing temperature from $45^{\circ} \mathrm{C}$ to $95^{\circ} \mathrm{C}\left(0.5^{\circ} \mathrm{C} / 10 \mathrm{~s}\right)$ and gel and gel electrophoresis of final product confirmed single amplicons. Negative control reactions using untranscribed RNA were also run to confirm absence of genomic DNA. The relative fold change for a particular target was determined by comparing the $\mathrm{Ct}$ values for the treatment with that of the control. The Ct values were normalized using the $\mathrm{Ct}$ reference (actin) prior to comparison.

\section{Authors' contributions}

NM carried out most of the work described here including conception and design of experiments, acquisition of data, analysis and interpretation of data and drafting the manuscript. RF and EP contributed towards conception and design of experiments, supervision of the work and critical review of the manuscript. TC contributed towards design of experiments, analysis and interpretation of data and review of manuscript. All authors read and approved the final manuscript.

\section{Additional material}

\section{Additional file 1}

Genes $>2$-fold differentially expressed between drought stressed and unstressed plants (sorted with respect to their putative function). The genes $>2$-fold differentially expressed between drought stressed and unstressed plants. The table has been sorted with respect to putative function of genes and details of genotype/tissue-type in which the genes were expressed are given.

Click here for file

[http://www.biomedcentral.com/content/supplementary/1471-

2164-8-303-S1.xls]

\section{Additional file 2}

Genes $>2$-fold differentially expressed between cold stressed and unstressed plants (sorted with respect to their putative function). The genes $>2$-fold differentially expressed between cold stressed and unstressed plants. The table has been sorted with respect to putative function of genes and details of genotype/tissue-type in which the genes were expressed are given.

Click here for file

[http://www.biomedcentral.com/content/supplementary/14712164-8-303-S2.xls] 


\section{Additional file 3}

Genes $>2$-fold differentially expressed between high-salinity stressed and unstressed plants (sorted with respect to their putative function). The genes $>2$-fold differentially expressed between high-salinity stressed and unstressed plants. The table has been sorted with respect to putative function of genes and details of genotype/tissue-type in which the genes were expressed are given.

Click here for file

[http://www.biomedcentral.com/content/supplementary/14712164-8-303-S3.xls]

\section{Additional file 4}

Characteristics of the 768 microarray features. The details of the 768 features printed on the spotted cDNA array. It includes the Spot position, GenBank ${ }^{\varpi}$ Accession, Gene Name, Source, Biosequence type and its usage (reporter/control).

Click here for file

[http://www.biomedcentral.com/content/supplementary/14712164-8-303-S4.pdf]

\section{Acknowledgements}

This work was supported by Bioversity International (formerly, International Plant Genetic Resources Institute) by offering Vavilov-Frankel Fellowship to the first author. We thank Dr. David Hoisington, Dr. Vadez Vincent, Dr. Heather Clarke, Dr. Bhag Mal, Dr. Carmen de Vicente and Moses Maliro for their critical advice during planning and execution of these experiments. We are grateful to Dr. Bob Redden for providing important information on selection of genotypes and supply of seeds.

\section{References}

I. Ahmad F, Gaur P, Croser J: Chickpea (Cicer arietinum L.). In Genetic Resources, Chromosome Engineering and Crop Improvement Grain Legumes Volume I. Edited by: USA: CRC Press. Singh R, Jauhar P; 2005:185-214.

2. Skrypetz S: Australia: Pulse and Special Crops, Situation and Outlook. Bi-weekly Bulletin, Agriculture and Agri-Food Canada 2006, 19:1-4.

3. Singh K: Chickpea breeding. In The Chickpea Edited by: Saxena M, Singh K. Wallingford: CAB International; 1987: 127-162.

4. Ryan J: A global perspective on pigeon pea and chickpea sustainable production systems: present status and future potential. In Recent Advances in Pulses Research Edited by: Asthana A, Ali M. Kanpur, India: Indian Society for Pulses Research and Development; | $997:|-3|$.

5. Millan T, Clarke H, Siddique K, Buhariwalla H, Gaur P, Kumar J, Gil J, Kahl G, Winter P: Chickpea molecular breeding: New tools and concepts. Euphytica 2006, I47(I):8I-103.

6. Munns R, Husain S, Rivelli A, James R, Condon A, Lindsay M, Lagudah $E$, Schachtman D, Hare R: Avenues for increasing salt tolerance of crops, and the role of physiologically based selection traits. Plant Soil 2002, 247(I):93-105.

7. Wang W, Vinocur B, Altman A: Plant responses to drought salinity and extreme temperatures: towards genetic engineering for stress tolerance. Planta 2003, 2 | 8(I): I- | 4 .

8. Udupa S, Sharma A, Sharma R, Pai R: Narrow genetic variability in Cicer arietinum $L$. as revealed by RFLP analysis. J Plant Biochem Biotechnol 1993, 2:83-86.

9. Banerjee $H$, Pai R, JP M, Sharma R: Use of random amplified polymorphic DNA markers for mapping the chickpea genome. Biol Plantarum 200I, 44(2): I 95-202.

10. Cobos M, Rubio J, Strange R, Moreno M, Gil J, Millan T: A new QTL for Ascochyta blight resistance in an RIL population derived from an interspecific cross in chickpea. Euphytica 2006, 149(1): 105-III.

II. Collard B, Pang E, Ades P, Taylor P: Preliminary investigation of QTLs associated with seedling resistance to ascochyta blight from Cicer echinospermum, a wild relative of chickpea. Theor Appl Genet 2003, 107(4):719-729.

12. Kazan K, Muehlbauer F, Weeden N, Ladizinsky G: Inheritance and linkage relationships of morphological and isozyme loci in chickpea (Cicer arietinum L.). Theor Appl Genet 1993, 86(4):417-426.

13. Pfaff $\mathrm{T}, \mathrm{Kahl} \mathrm{G}$ : Mapping of gene-specific markers on the genetic map of chickpea (Cicer arietinum L.). Mol Genet Genomics 2003, 269(2):243-25I.

14. Ratnaparkhe M, Santra D, Tullu A, Muehlbauer F: Inheritance of inter-simple-sequence-repeat polymorphisms and linkage with a fusarium wilt resistance gene in chickpea. Theor Appl Genet 1998, 96(3):348-353.

15. Santra D, Tekeoglu M, Ratnaparkhe M, Kaiser W, Muehlbauer F: Identification and Mapping of QTLs Conferring Resistance to Ascochyta Blight in Chickpea. Crop Sci 2000, 40(6):1606-1612.

16. Simon C, Muehlbauer F: Construction of a chickpea linkage map and its comparison with maps of pea and lentil. J Hered 1997, 88:115-119.

17. Tekeoglu M, Santra D, Kaiser W, Muehlbauer F: Ascochyta Blight Resistance Inheritance in Three Chickpea Recombinant Inbred Line Populations. Crop Sci 2000, 40: I25I-I 256.

18. Winter $P$, Benko-Iseppon A, Hüttel B, Ratnaparkhe M, Tullu A, Sonnante G, Pfaff T, Tekeoglu M, Santra D, Sant V: A linkage map of the chickpea (Cicer arietinum L.) genome based on recombinant inbred lines from a $C$. arietinum $\times C$. reticulatum cross: localization of resistance genes for fusarium wilt races 4 and 5. Theor Appl Genet 2000, 101 (7): II55-II63.

19. Cho S, Kumar J, Shultz J, Anupama K, Tefera F, Muehlbauer F: Mapping genes for double podding and other morphological traits in chickpea. Euphytica 2002, I 28(2):285-292.

20. Cobos M, Fernández M, Rubio J, Kharrat M, Moreno M, Gil J, Millán $\mathrm{T}$ : A linkage map of chickpea (Cicer arietinum L.) based on populations from Kabuli $\times$ Desi crosses: location of genes for resistance to fusarium wilt race 0 . Theor Appl Genet 2005, I I 0(7): 1347-1353.

2I. Flandez-Galvez H, Ades P, Ford R, Pang E, Taylor P: QTL analysis for ascochyta blight resistance in an intraspecific population of chickpea (Cicer arietinum L.). Theor Appl Genet 2003, I07(7): I257-I 265.

22. Udupa S, Baum M: Genetic dissection of pathotype-specific resistance to ascochyta blight disease in chickpea (Cicer arietinum L.) using microsatellite markers. Theor Appl Genet 2003, 106(7): I I 96-1202.

23. Tuberosa R, Salvi S: Markers, genomics and postgenomics approaches-Will they assist in selecting for drought tolerance. In New Directions for a Diverse Planet: Proceedings for the 4th International Crop Science Congress: 2004 Brisbane, Australia: Crop Science Society; 2004.

24. Schena M, Shalon D, Davis R, Brown P: Quantitative monitoring of gene expression patterns with a complementary DNA microarray. Science 1995, 270(5235):467-470.

25. Buchanan C, Lim S, Salzman R, Kagiampakis I, Morishige D, Weers B, Klein R, Pratt L, Cordonnier-Pratt M, Klein P: Sorghum bicolor's Transcriptome Response to Dehydration, High Salinity and ABA. Plant Mol Biol 2005, 58(5):699-720.

26. Diab A, Teulat-Merah B, This D, Ozturk N, Benscher D, Sorrells M: Identification of drought-inducible genes and differentially expressed sequence tags in barley. Theor Appl Genet 2004, 109(7): $1417-1425$

27. Rabbani M, Maruyama K, Abe H, Khan M, Katsura K, Ito Y, Yoshiwara K, Seki M, Shinozaki K, Yamaguchi-Shinozaki K: Monitoring Expression Profiles of Rice Genes under Cold, Drought, and HighSalinity Stresses and Abscisic Acid Application Using cDNA Microarray and RNA Gel-Blot Analyses I [w]. Plant Physiol 2003, I33(4): 1755-1767.

28. Rensink W, lobst S, Hart A, Stegalkina S, Liu J, Buell C: Gene expression profiling of potato responses to cold, heat, and salt stress. Functional \& Integrative Genomics 2005, 5(4):20I-207.

29. Seki M, Narusaka M, Ishida J, Nanjo T, Fujita M, Oono Y, Kamiya A, Nakajima M, Enju A, Sakurai T: Monitoring the expression profiles of 7000 Arabidopsis genes under drought, cold and highsalinity stresses using a full-length cDNA microarray. The Plant J 2002, 3 I (3):279-292.

30. Plant Genomes Central - Genome Projects in Progress [http://www.ncbi.nlm.nih.gov/genomes/PLANTS/PlantList.html] 
31. Coram T, Pang E: Isolation and analysis of candidate ascochyta blight defence genes in chickpea. Part I. Generation and analysis of an expressed sequence tag(EST) library. Physiol Mol Plant P 2005, 66(5): 192-200.

32. Skiba B, Ford R, Pang E: Construction of a cDNA library of Lathyrus sativus inoculated with Mycosphaerella pinodes and the expression of potential defence-related expressed sequence tags (ESTs). Physiol Mol Plant P 2005, 66(1/2):55-67.

33. Coram T, Pang E: Expression profiling of chickpea genes differentially regulated during a resistance response to Ascochyta rabiei. Plant Biotechnol J 2006, 4(6):647-666.

34. Kreps J, Wu Y, Chang H, Zhu T, Wang X, Harper J: Transcriptome Changes for Arabidopsis in Response to Salt, Osmotic, and Cold Stress. Plant Physiol 2002, I30(4):2 I29-2 I 4I.

35. Cheong Y, Chang H, Gupta R, Wang X, Zhu T, Luan S: Transcriptional Profiling Reveals Novel Interactions between Wounding, Pathogen, Abiotic Stress, and Hormonal Responses in Arabidopsis. Plant Physiol 2002, I 29(2):66I-677.

36. Munns R: Tansley review: Genes and salt tolerance: bringing them together. New Phytol 2005, I 67(3):645-663.

37. Fujita M, Fujita Y, Noutoshi Y, Takahashi F, Narusaka Y, YamaguchiShinozaki K, Shinozaki K: Crosstalk between abiotic and biotic stress responses: a current view from the points of convergence in the stress signaling networks. Curr Opin Plant Biol 2006, 9(4):436-442.

38. Clarke H, Siddique K: Response of chickpea genotypes to low temperature stress during reproductive development. Field Crop Res 2004, 90(2/3):323-334.

39. Khanna-Chopra R, Sinha S: Chickpea: physiological aspects of growth and yield. In The Chickpea Edited by: Saxena M, Singh K. Wallingford: CAB International; 1987: 163-189.

40. Nayyar H, Chander K, Kumar S, Bains T: Glycine betaine mitigates cold stress damage in chickpea. Agron Sustain Dev 2005 25(3):38I-388.

41. Srinivasan A, Saxena N, Johansen C: Cold tolerance during early reproductive growth of chickpea (Cicer arietinum L.): genetic variation in gamete development and function. Field Crop Res 1999, 60(3):209-222.

42. Dowd C, Wilson I, McFadden H: Gene expression profile changes in cotton root and hypocotyl tissues in response to infection with Fusarium oxysporum f. sp. vasinfectum. Mol Plant Microbe In 2004, I 7(6):654-667.

43. Lopez C, Soto M, Restrepo S, Piégu B, Cooke R, Delseny M, Tohme J, Verdier V: Gene expression profile in response to $\mathrm{Xan}$ thomonas axonopodis pv. manihotis infection in cassava using a cDNA microarray. Plant Mol Biol 2005, 57(3):393-4I 0.

44. Jang JY, Kim DG, Kim YO, Kim JS, Kang H: An Expression Analysis of a Gene Family Encoding Plasma Membrane Aquaporins in Response to Abiotic Stresses in Arabidopsis Thaliana. Plant Mol Biol 2004, 54(5):7। 3-725.

45. Jiang $Y$, Deyholos MK: Comprehensive transcriptional profiling of $\mathrm{NaCl}$-stressed Arabidopsis roots reveals novel classes of responsive genes. BMC Plant Biology 2006, 6(I):25

46. Kawaura K, Mochida K, Yamazaki Y, Ogihara Y: Transcriptome analysis of salinity stress responses in common wheat using a 22 k oligo-DNA microarray. Functional \& Integrative Genomics 2006, 6(2): $132-142$

47. Oh SJ, Song SI, Kim YS, Jang HJ, Kim SY, Kim M, Kim YK, Nahm BH, Kim JK: Arabidopsis CBF3/DREB I A and ABF3 in Transgenic Rice Increased Tolerance to Abiotic Stress without Stunting Growth I [w]. Plant Physiol 2005, I 38(I):34 I-35I.

48. Walia $\mathrm{H}$, Wilson $\mathrm{C}$, Condamine $\mathrm{P}$, Liu $\mathrm{X}$, Ismail AM, Zeng L, Wana maker SI, Mandal J, Xu J, Cui X: Comparative Transcriptional Profiling of Two Contrasting Rice Genotypes under Salinity Stress during the Vegetative Growth Stage I [w]. Plant Physiol 2005, I 39(2):822-835.

49. Zhou J, Wang X, Jiao Y, Qin Y, Liu X, He K, Chen C, Ma L, Wang J, Xiong L: Global genome expression analysis of rice in response to drought and high-salinity stresses in shoot, flag leaf, and panicle. Plant Mol Biol 2007, 63(5):59l-608.

50. Park S, Han K: An auxin-repressed gene (RpARP) from black locust (Robinia pseudoacacia) is posttranscriptionally regulated and negatively associated with shoot elongation. Tree Physiol 2003, 12:815-823.

51. Essential Role Of Phosphorus (P) In Plants [http://www.agcen tral.com/imcdemo/06Phosphorus/06-01.htm]
52. Leslie S, Israeli E, Lighthart B, Crowe J, Crowe L: Trehalose and sucrose protect both membranes and proteins in intact bacteria during drying. Appl Environ Microb 1995, 6 I ( I 0):3592-3597.

53. Mitra J: Genetics and genetic improvement of drought resistance in crop plants. Curr Sci India 200I, 80(6):758-763.

54. Van Heerden P, Krüger G: Photosynthetic limitation in soybean during cold stress. S Afr J Sci 2000, 96:20I-206.

55. Wolk W, Herner R: Chilling injury of germinating seeds and seedlings. HortScience 1982, I 7(2): 169-I73.

56. Yohn C, Cohen A, Danon A, Mayfield S: A poly (A) binding protein functions in the chloroplast as a message-specific translation factor. Proceedings of the National Academy of Sciences, USA 1998, 95(5):2238-2243.

57. Martz F, Maury S, Pinçon G, Legrand M: cDNA cloning, substrate specificity and expression study of tobacco caffeoyl-CoA 3 O-methyltransferase, a lignin biosynthetic enzyme. Plant Mol Biol 1998, 36(3):427-437.

58. Keller B, Baumgartner C: Vascular-Specific Expression of the Bean GRP I.8 Gene Is Negatively Regulated. The Plant Cell Online |99|, 3(10): |05|-|061.

59. Urao T, Yamaguchi-Shinozaki K, Shinozaki K: Two-component systems in plant signal transduction. Trends Plant Sci 2000 , 5(2):67-74.

60. Xiong L, Schumaker K, Zhu J: Cell Signaling during Cold, Drought, and Salt Stress. The Plant Cell Online 2002, I 4: I65-I83.

6I. Neill S, Desikan R, Hancock J: Hydrogen peroxide signalling. Curr Opin Plant Biol 2002, 5(5):388-395

62. Minic Z, Rihouey C, Do C, Lerouge P, Jouanin L: Purification and Characterization of Enzymes Exhibiting $\beta$-d-Xylosidase Activities in Stem Tissues of Arabidopsis I. Plant Physiol 2004, I 35(2):867-878.

63. Gygi S, Rochon Y, Franza B, Aebersold R: Correlation between Protein and mRNA Abundance in Yeast. Mol Cell Biol 1999 , 19(3): $1720-1730$

64. Ray J, Sinclair T: The effect of pot size on growth and transpiration of maize and soybean during water deficit stress. J Exp Bot 1998, 49:|38|-|386.

65. Croser J, Clarke H, Siddique K, Khan T: Low-Temperature Stress: Implications for Chickpea (Cicer arietinum L.) Improvement. Crit Rev Plant Sci 2003, 22(2): 185-219.

66. Taiz L, Zeiger E: Plant Physiology. 3rd edition. Massachusetts: Sinauer Associates, Inc; 2002.

67. Brazma A, Hingamp P, Quackenbush J, Sherlock G, Spellman P, Stoeckert C, Aach J, Ansorge W, Ball C, Causton H: Minimum information about a microarray experiment (MIAME)toward standards for microarray data. Nat Genet 200I, 29(4):365-37।.

68. Berger J, Hautaniemi S, Järvinen A, Edgren H, Mitra S, Astola J: Optimized LOWESS normalization parameter selection for DNA microarray data. BMC Bioinformatics 2004, 5: 194.

69. Rozen S, Skaletsky H: Primer3 on the WWW for general users and for biologist programmers. In Bioinformatics Methods and Protocols: Methods in Molecular Biology Edited by: Krawetz S, Misener S. Totowa, NJ: Humana Press; 2000:365-386.

Publish with Bio Med Central and every scientist can read your work free of charge

"BioMed Central will be the most significant development for disseminating the results of biomedical research in our lifetime. "

Sir Paul Nurse, Cancer Research UK

Your research papers will be:

- available free of charge to the entire biomedical community

- peer reviewed and published immediately upon acceptance

- cited in PubMed and archived on PubMed Central

- yours - you keep the copyright
BioMedcentral 